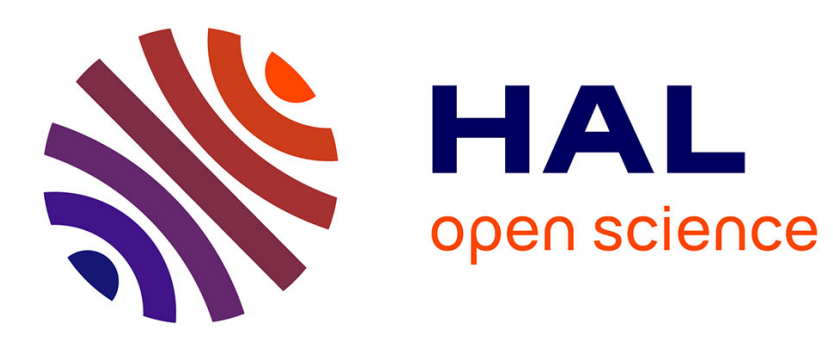

\title{
Bisphenol-A alters gene expression and functional parameters in molluscan hepatopancreas
}

Laura Canesi, Cristina Borghi, Caterina Ciacci, Rita Fabbri, Laura Vergani, Gabriella Gallo

\section{- To cite this version:}

Laura Canesi, Cristina Borghi, Caterina Ciacci, Rita Fabbri, Laura Vergani, et al.. Bisphenol-A alters gene expression and functional parameters in molluscan hepatopancreas. Molecular and Cellular Endocrinology, 2007, 276 (1-2), pp.36. 10.1016/j.mce.2007.06.002 . hal-00531936

\section{HAL Id: hal-00531936 https://hal.science/hal-00531936}

Submitted on 4 Nov 2010

HAL is a multi-disciplinary open access archive for the deposit and dissemination of scientific research documents, whether they are published or not. The documents may come from teaching and research institutions in France or abroad, or from public or private research centers.
L'archive ouverte pluridisciplinaire HAL, est destinée au dépôt et à la diffusion de documents scientifiques de niveau recherche, publiés ou non, émanant des établissements d'enseignement et de recherche français ou étrangers, des laboratoires publics ou privés. 


\section{Accepted Manuscript}

Title: Bisphenol-A alters gene expression and functional parameters in molluscan hepatopancreas

Authors: Laura Canesi, Cristina Borghi, Caterina Ciacci, Rita Fabbri, Laura Vergani, Gabriella Gallo

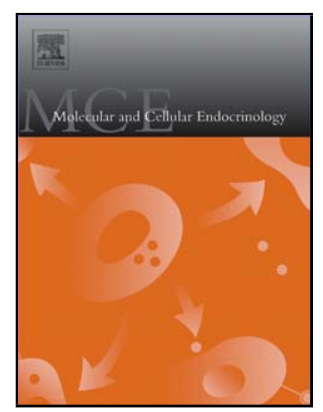

PII:

S0303-7207(07)00239-0

DOI: doi:10.1016/j.mce.2007.06.002

Reference: MCE 6675

To appear in: $\quad$ Molecular and Cellular Endocrinology

Received date: $\quad$ 7-5-2007

Revised date: $\quad 18-6-2007$

Accepted date: $\quad$ 22-6-2007

Please cite this article as: Canesi, L., Borghi, C., Ciacci, C., Fabbri, R., Vergani, L., Gallo, G., Bisphenol-A alters gene expression and functional parameters in molluscan hepatopancreas, Molecular and Cellular Endocrinology (2007), doi:10.1016/j.mce.2007.06.002

This is a PDF file of an unedited manuscript that has been accepted for publication. As a service to our customers we are providing this early version of the manuscript. The manuscript will undergo copyediting, typesetting, and review of the resulting proof before it is published in its final form. Please note that during the production process errors may be discovered which could affect the content, and all legal disclaimers that apply to the journal pertain. 


\title{
Bisphenol-A alters gene expression and functional parameters in molluscan hepatopancreas
}

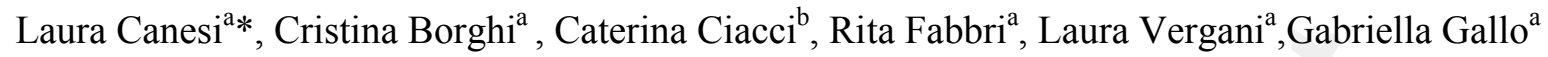 \\ ${ }^{a}$ Dipartimento di Biologia, Università di Genova, Corso Europa 26, 16132, Genova; ${ }^{b}$ Istituto di \\ Scienze Fisiologiche, Università di Urbino, Italy.
}

*Corresponding Author:

Laura Canesi

Dipartimento di Biologia, Università di Genova, Corso Europa 26, 16132 - Italy.

Tel: +390103538241

Fax: +390103538267

Laura.Canesi@unige.it

Key words: xenoestrogens, bivalve molluscs, hepatopancreas, estrogen receptors, metallothionein, redox balance, 


\begin{abstract}
Bisphenol A (BPA) is a well-known xenoestrogen in mammalian systems that can affect reproduction also in aquatic organisms. In this work the possible effects of BPA were investigated in the hepatopancreas of the bivalve mollusc Mytilus galloprovincialis: mussels were injected with different amounts of BPA (3-60 ng/g dw tissue) and tissues sampled at $24 \mathrm{~h}$ post-injection. Expression of different Mytilus genes was evaluated by RT-Q-PCR: BPA exposure increased the expression of MeER2 and induced downregulation of antioxidant genes, catalase and metallothioneins. Moreover, BPA induced changes in activity of catalase, GSH transferase (GST) and GSSG reductase (GSR), and in total glutathione content. A decrease in lysosomal membrane stability and increased neutral lipid accumulation were also observed. The results were compared with those obtained with similar concentrations of $17 \beta$-estradiol. These data demonstrate that BPA can alter gene expression, activities of enzymes involved in redox balance, and lysosomal function in molluscan hepatopancreas, a tissue involved in the control of metabolism and gamete maturation. Overall, these data indicate that BPA, at environmentally relevant concentrations, can have both estrogen-like and distinct effects in invertebrates like in vertebrates.
\end{abstract}

Keywords: xenoestrogens, molluscs, Mytilus digestive gland, gene expression, estrogen receptors, antioxidant defences, lysosomes. 


\section{Introduction}

Xenoestrogens are environmental chemicals that mimic the natural steroid $17 \beta$-estradiol, potentially interfering with the physiological action of the hormone. The concept of estrogenicity is generally based on the property of these compounds to bind estrogen receptors (ERs), and to act as transcription factors, when binding to the estrogen response elements (ERE) in the DNA, thus affecting gene expression (Soto et al., 2006). However, estrogens can also act through rapid, 'non genomic' mechanisms of action that may be initiated at either membrane or cytosolic locations and can result in both direct local effects (such as changes in ion fluxes) and regulation of gene transcription secondary to activation of cytosolic kinase cascades (Levin, 2005; Vasudevan and Pfaff, 2007). Recent studies demonstrated that xenoestrogens can rapidly and potently elicit signaling through non genomic pathways culminating in functional endpoints (Walsh et al., 2005; Ropero et al., 2006; Tabb and Blumberg, 2006; Waring and Harris, 2005; Watson et al., 2007).

For invertebrates, which represent $95 \%$ of animal species, information on the effects and mechanisms of action of estrogens is scarce compared to that available in vertebrates, given the complexity of endocrine systems in different phyla (Oehlmann et al., 2006; Porte et al., 2006). However, this subject is receiving increasing attention due to the concern posed by the presence in the environment of both natural and synthetic steroid estrogens, as well as a variety of estrogenmimicking chemicals, that represent a potential hazard for humans and wildlife species (McLachlan, 2001; Rotchell and Ostrander, 2003; Waring and Harris, 2005). The presence of most vertebrate sex steroids and steroidogenic pathways has been described in different invertebrate groups, molluscs in particular, where the role of estrogens has been mainly investigated in the control of gametogenesis (Porte et al., 2006; Janer and Porte, 2007). Estrogen-like receptors have been recently characterized in gastropods (Thornton et al., 2003; Kajiwara et al., 2006) and cephalopods (Keay et al., 2006) and ER-like sequences have been identified in bivalves (Puinean et al., 2006). Molluscan ERs, although phylogenetically clustered with other steroid receptors, 
appear to be functionally different: their transcriptional activity is constitutive, and not activated by estrogens (Thornton et al., 2003; Keay et al., 2006). However, in ganglia and immune cells of the bivalve Mytilus, 17 $\beta$-estradiol $\left(\mathrm{E}_{2}\right)$ has been shown to act through rapid, 'alternative' modes of action through modulation of $\mathrm{Ca}^{2+}$ - and kinase-mediated cascades (Stefano et al., 2003; Canesi et al., 2004a, 2006). Moreover, we have recently demonstrated that in Mytilus hepatopancreas (or digestive gland), a tissue that plays a central role in metabolism, $\mathrm{E}_{2}$ modulates different functional parameters and increases the expression of antioxidant genes (Canesi et al., 2007). These data support the hypothesis that, although the molluscan ERs do not appear to mediate genomic estrogen signaling, conserved nongenomic mechanisms via 'alternative' modes of action are likely candidates for this role (Keay et al., 2006).

The xenoestrogen Bisphenol A-BPA (2,2-bis-(4-hydroxyphenyl)-propane) is a monomer used in the manufacture a variety of plastic products. In mammalian systems, BPA induces estrogenic activity through both genomic and rapid, non genomic pathways, involving both ER-dependent and ERindependent mechanism of action, depending on both cell and tissue type (Gould et al., 1998; Quesada et al., 2002; Singleton et al., 2004; Maffini et al., 2006; Ropero et al., 2006). BPA is produced in large amounts and it is detected at high levels in human samples as well as in aquatic organisms (vom Saal and Hughes, 2005), where it has been shown to induce significant disruption of reproductive output, with molluscs being apparently more sensitive than fish (Jobling et al., 2003; Ohelmann et al., 2006). Concentrations of BPA ranging from ng to $\mu \mathrm{g} / \mathrm{l}$ can be found in the coastal marine environment (Pojana et al., 2004; Anderson et al., 2006).

In Mytilus immunocytes, BPA rapidly affected the lysosomal function both in vitro (Canesi et al., 2004b) and in vivo (Canesi et al, 2005); these effects were mediated by interference with components of rapid kinase-mediated cell signalling that are activated by $\mathrm{E}_{2}$ (Canesi et al., 2004a; 2006; Porte et al., 2006). In this work, the possible effects of BPA on gene expression and functional parameters of mussel hepatopancreas were investigated and the results compared with those obtained with $\mathrm{E}_{2}$ in the same experimental conditions (Canesi et al., 2007). Mussels were 
injected with different amounts of BPA and tissues sampled at $24 \mathrm{hrs}$ post-injection. In bivalves, direct administration into the blood (hemolymph) by injection into the adductor muscle sinus has been widely utilised for identifying the possible targets of both natural and environmental estrogens (Gagnè et al., 2001; Canesi et al., 2005, 2006, 2007; Le Curieux-Belfond et al., 2005; GauthierClerc et al., 2006; Puinean and Rotchell, 2006). The concentrations of BPA (ng/g dry weight/mussel) were in the same range as those previously shown to affect mussel immune parameters in the same experimental conditions (Canesi et al., 2005) and comparable to environmental exposure levels (Pojana et al., 2004).

Expression of Mytilus ERs (MeER1, MeER2) as well as of other genes (catalase, metallothionein isoforms MT10 and MT20, p53, cathepsin L) was evaluated by quantitative RT-PCR. Moreover, the activity of enzymes involved in tissue redox balance (catalase, GSH transferase, GSSG reductase), and the concentration of total glutathione (GSH+GSSG), as well as lysosomal parameters (lysosomal membrane stability-LMS and accumulation of neutral lipids-NL, lipofuscin) were evaluated. 


\section{Materials and methods}

\subsection{Animals and treatments}

Mussels (Mytilus galloprovincialis Lam.) 4-5 cm long, were obtained from a fishermen cooperative (SEA-Gabicce Mare, PU) in October 2006. Mussels were kept for 1-3 days in static tanks containing artificial sea water (ASW) $(1 \mathrm{l} / \mathrm{mussel})$ at $16^{\circ} \mathrm{C}$. Sea water was changed daily. In mussels of this size, average dry weight of soft tissues was $1 \mathrm{~g}$, the average volume of hemolymph that can be withdrawn from each animal was about $1 \mathrm{ml}$; average concentration of free $\mathrm{E}_{2}$ in the hemolymph of control mussels was $0,8-1 \mathrm{ng} / \mathrm{ml}$ (evaluated by a commercial competitive chemiluminescent enzyme immunoassay kit (Immulite 2000 Estradiol).

BPA was injected into the posterior adductor muscle of groups of 10-12 mussels each, using a sterile $1 \mathrm{ml}$ syringe with a 18G1/2" needle as previously described (Canesi et al., 2005). In bivalve molluscs, injection into the adductor muscle sinus allows for direct administration of estrogens into the animal open circulatory system leading distribution from the blood (hemolymph) to the tissues, including the hepatopancreas (Le Curieux-Belfond et al., 2005). This method has been largely utilised for evaluating the effects of natural and environmental estrogens in bivalves (Gagnè et al., 2001; Canesi et al., 2005, 2006, 2007; Gauthier-Clerc et al., 2006; Puinean and Rotchell, 2006).

Each mussel was injected with $50 \mu$ of BPA solutions (from a $10 \mathrm{mM}$ stock solution in ethanol diluted in ASW), containing, respectively 3, 15, and $60 \mathrm{ng}$ BPA, corresponding to a nominal concentration of BPA 3, 15, and $60 \mathrm{ng} / \mathrm{g}$ dry weight or per mussel. Similarly, groups of 10-12 mussels were injected with 1,35 and $6,75 \mathrm{ng} 17 \beta$-estradiol $\left(\mathrm{E}_{2}\right)$ (nominal concentrations of 1,35 and $6,75 \mathrm{ng} / \mathrm{g} \mathrm{dw}$ or per mussel), as previously described (Canesi et al., 2006, 2007). For each experiment, a parallel set of control mussels were injected with $50 \mu$ of a solution of ASW containing an equal amount of ethanol $(\leq 0.005 \%)$. Mussels were then placed in plastic tanks containing $\mathrm{ASW}$ at $16{ }^{\circ} \mathrm{C}(0.5 \mathrm{l} / \mathrm{mussel})$. Experiments were repeated three times. At $24 \mathrm{hrs}$ post- 
injection, digestive glands were rapidly dissected fro each group of mussels, pooled and frozen in liquid nitrogen and maintained at $-80^{\circ} \mathrm{C}$. For histological analyses, small pieces of digestive glands were placed on aluminium chucks, immersed in hexane pre-cooled to $-70^{\circ} \mathrm{C}$ in liquid nitrogen and maintained at $-80^{\circ} \mathrm{C}$ (Moore, 1976). Animals were not fed during the experiment.

\subsection{RNA isolation and quantitative RT-PCR}

Total RNA was extracted from 0.5 grams of frozen pools of digestive glands using Trizol Reagent (Sigma) following the manufacturer's protocol. The quality of the isolated RNA was checked by gel electrophoresis. The concentration and purity of the isolated RNA were assessed by absorption spectroscopy. Only samples with $\mathrm{OD}_{260} / 280>1.8$ were processed. Aliquots of $1 \mu \mathrm{g}$ of total RNA were reverse-transcribed into cDNA using 200 units of RevertAid H-Minus M-MuLV Reverse Trascriptase (Fermentas, Hannover MD, USA), in the presence of $250 \mathrm{ng}$ of random examers (Invitrogen, Milan, Italy), $1 \mathrm{mM} \mathrm{dNTPs}$ (Promega, Milan, Italy) at $42^{\circ} \mathrm{C}$ for $60 \mathrm{~min}$ in a reaction volume of $20 \mu \mathrm{l}$. cDNA was then utilized to amplify the target sequences of interest using a Chromo $4^{\mathrm{TM}}$ System real-time PCR apparatus (Biorad, Milan, Italy). Aliquots of cDNA samples were suitably diluted in a final volume of $20 \mu$ containing 1x iTaq SybrGreen Supermix with Rox (Biorad, Milan, Italy) and $0.25 \mu \mathrm{M}$ of each primer (TibMolBiol, Genoa, Italy). The primer pairs utilized and their references are shown in Tab. 1. The thermal protocol consisted of 3 min initial denaturation at $95 \mathrm{C}$, followed by 40 cycles: $15 \mathrm{~s}$ at $95 \mathrm{C} ; 30 \mathrm{~s}$ at $55^{\circ} \mathrm{C}\left(30 \mathrm{~s}\right.$ at $51^{\circ} \mathrm{C}$ and $54^{\circ} \mathrm{C}$ for MeER1 and MeER2 respectively); $20 \mathrm{~s}$ at $72^{\circ} \mathrm{C}$. A melting curve of PCR products $\left(55-94{ }^{\circ} \mathrm{C}\right)$ was also performed to ensure the absence of artefacts. Relative expression of target genes in comparison with the $18 \mathrm{~S}$ reference gene was evaluated by the comparative $\mathrm{C}_{\mathrm{T}}$ threshold method (Pfaffl, 2001) using the Biorad software tool Genex-Gene Expression Macro ${ }^{\mathrm{TM}}$ (Vandesompele et al, 2002). The normalized expression obtained was expressed as relative quantity of mRNA with respect to control samples. Data are the mean $\pm \mathrm{SD}$ fo three experiments in quadruplicate. 


\subsection{Determination of enzyme activities and glutathione content}

Catalase: tissues were homogenized in 5 vol of homogenization buffer $(20 \mathrm{mM}$ Tris buffer, $0.5 \mathrm{M}$ sucrose, $0,15 \mathrm{M} \mathrm{NaCl}, \mathrm{pH} 7.6)$ and centrifuged at $500 \mathrm{x}$ g for $15 \mathrm{~min}$ at $4^{\circ} \mathrm{C}$. The supernatants were then centrifuged at $12,000 \times \mathrm{g}$ for $30 \mathrm{~min}$. Both supernatant and pellet, (containing mitochondria and peroxisomes) were utilised for the spectrophotometric evaluation of catalase activity following the decomposition of $\mathrm{H}_{2} \mathrm{O}_{2}$ at $\mathrm{pH} 7,25^{\circ} \mathrm{C}$, at $240 \mathrm{nM}$ as previously described (Viarengo et al., 1991).

GSH transferase (GST) and GSSG reductase (GSR) activities were evaluated as previously described (Canesi and Viarengo, 1997). Digestive glands were homogenised in 4 vol of homogenization buffer and centrifuged at $100,000 \mathrm{x}$ g for $90 \mathrm{~min}$ at $0-4{ }^{\circ} \mathrm{C}$. Aliquots of the supernatants were utilized for the spectophotometric determination of enzyme activities. GST activity was evaluated with CDNB (1-chloro-2,4-dinitrobenzene) as a substrate. The reaction mixture $(1 \mathrm{ml})$ contained $125 \mathrm{mM} \mathrm{K-phosphate} \mathrm{buffer,} \mathrm{pH} \mathrm{6.5,} 1 \mathrm{mM}$ CDNB, $1 \mathrm{mM}$ GSH. The formation of S-2,4-dinitro phenyl glutathione conjugate was evaluated by monitoring the increase in absorbance at $340 \mathrm{~nm}$. GSR activity was estimated in $1 \mathrm{ml}$ of a reaction mixture containing $125 \mathrm{mM}$ K-phosphate buffer, $\mathrm{pH}$ 7.5, 0,05 nM NADPH, $1 \mathrm{mM} \mathrm{GSH}$. The NADPH oxidation was evaluated by monitoring the increase in absorbance at $340 \mathrm{~nm}$.

Assay for total glutathione: digestive glands were homogenised in 4 vol of $1 \mathrm{~N}$ perchloric acid, 2 $\mathrm{mM}$ EDTA and then centrifuged at $16,000 \times \mathrm{g}$ for $20 \mathrm{~min}$ at $4{ }^{\circ} \mathrm{C}$. The supernatants were neutralized with $2 \mathrm{M} \mathrm{KOH}, 0.3 \mathrm{M}$ morpholin ethanol sulphonic acid (MOPS) and centrifuged at $1,000 \mathrm{x} \mathrm{g}$ for $10 \mathrm{~min}$ at $4{ }^{\circ} \mathrm{C}$. Aliquots of the neutralized supernatant were utilized for the evaluation of the total glutathione concentration (i.e. molar sum of GSH+1/2 GSSG) as previously described (Canesi and Viarengo, 1997), utilizing the enzymatic GSSG reductase assay, in $1 \mathrm{ml}$ of a reaction mixture containing 0.1 M K-phosphate buffer, $1 \mathrm{mM}$ EDTA, pH 7.0, 0.2 mM NADPH, $0.06 \mathrm{mM}$ dithionitrobenzoic acid and $0.12 \mathrm{U}$ of GSSG reductase. Calibration was performed utilizing known 
concentrations of GSSG instead of samples. Protein content was determined according to the Lowry method using bovine serum albumin (BSA) as a standard.

\subsection{Lysosomal parameters}

Lysosomal membrane stability was evaluated in duplicate cryostat section of 5 digestive glands according to Moore (1988) and sections $(10 \mu \mathrm{m})$ were cut with a cryostat (Bright CM3050), flashdried by transferring them to room temperature, and then stained for $N$-acetyl- $\beta$-hexosaminidase activity (Moore, 1976). Digital images of the tissue sections were acquired by an Olympus BX60 microscope light microscope equipped with a scientific grade Color ViewII CCD Camera (Olympus, J). Staining intensity of lysosomes was determined at $400 \times$ magnification using the Scion Image software package (Scion Corp). Neutral lipid content was evaluated in cryostat sections of digestive glands fixed in calcium-formaldehyde (2\% Ca-acetate (w/v), $10 \%$ formaldehyde $(\mathrm{v} / \mathrm{v}))$ for $15 \mathrm{~min}$ at $4{ }^{\circ} \mathrm{C}$, followed by a rinsing step with de-ionised water, and incubation with 60\% triethylphosphate (TEP) for $3 \mathrm{~min}$ (Moore, 1988). The sections were then stained with Oil Red-O (1\% in 60\% TEP) for $30 \mathrm{~s}$, rinsed with de-ionised water, and mounted in $20 \%$ (v/v) glycerol. Lipofuscin content was determined using the Schmorl reaction on cryostat sections fixed in calcium-formaldehyde and rinsed with de-ionised water, as described for the neutral lipid assay, followed by a 5 min incubation step with $1 \% \mathrm{Fe}_{2} \mathrm{Cl}_{3}, 1 \%$ potassium ferrocyanide in a 3:1 ratio (Moore, 1988). The sections were rinsed with $1 \%$ acetic acid and mounted in $20 \%$ (v/v) glycerol. Neutral lipid and lipofuscin content were quantified by digital image analysis of stained sections, as described for the LMS assay. Results are reported as \% optical densities with respect to controls.

\subsection{Data analysis}

The results are the mean $\pm \mathrm{SD}$ of at least 3 experiments, each conducted with 10-12 mussels per experimental group, and analyses were performed in triplicate. Statistical analysis was performed 
by using the Mann-Whitney $\mathrm{U}$ test with significance at $\mathrm{P} \leq 0.05$.

\subsection{Chemicals}

All reagents were of analytical grade. Bisphenol A was from Sigma (St. Louis, MO). All other reagents were purchased from Sigma (St. Louis, MO). The PCR reagents were from Fermantas (St.Leon-Rot Germany), and Promega, Sigma, or Biorad (Milan, Italy). 


\section{Results}

\subsection{Effects of BPA on gene expression}

The possible effects of BPA exposure on the expression of different genes in mussel hepatopancreas were evaluated by quantitative RT-PCR, utilising the primer pairs reported in Tab. 1. Expression of the Mytilus ER gene sequences MeER1 and MeER2 was first evaluated in control animals by RTPCR: both sequences were expressed in mussel hepatopancreas, with MeER1 showing a higher basal expression with respect to MeER2 (Fig. 1A). As shown in Fig. 1B, BPA induced a significant decrease in the expression of MeER1 at $15 \mathrm{ng} / \mathrm{g} \mathrm{dw}(-54 \%$ with respect to controls; $\mathrm{P} \leq 0.05)$, whereas other concentrations were ineffective. On the other hand, a two-fold increase in the transcription of MeER2 was observed at all the concentrations tested, that was significant $(\mathrm{P} \leq 0.05)$ at the lowest concentration $(3 \mathrm{ng} / \mathrm{g})$. When mussels were exposed to $\mathrm{E}_{2}$, at concentrations previously shown to affect the expression of other genes in the hepatopancreas in the same experimental conditions (Canesi et al., 2007), a small increase in the amount of both MeER1 and MeER2 transcripts was observed, that was significant for MeER1 at $1.35 \mathrm{ng} / \mathrm{g}(+27 \%$; $\mathrm{P} \leq 0.05)$ and for MeER2 at 6,75 ng/g (+39\%; $\mathrm{P} \leq 0.05)$, respectively (Fig. 1C).

The effects of BPA on Mytilus gene sequences whose transcription has been previously shown to be modulated by $\mathrm{E}_{2}$ in mussel hepatopancreas in the same experimental conditions (Canesi et al., 2007) were also evaluated. Fig. 2 shows the results obtained for catalase, the two Mytilus metallothionein isoforms MT20 and MT10, and the p53-like gene. BPA induced a decrease in the transcription of catalase that was significant at $15 \mathrm{ng} / \mathrm{g}(-60 \% ; \mathrm{P} \leq 0.05)$, followed by recovery at the highest concentration. BPA induced downregulation of the MT20 gene at all the concentration tested (about $-60-70 \% ; \mathrm{P} \leq 0.05$ ); a significant decrease in the expression of MT10 was also observed at the highest concentration of $60 \mathrm{ng} / \mathrm{g}$ BPA $(-40 \%$; $\mathrm{P} \leq 0.05)$. A small but not significant decrease was seen for the transcription of the mussel p53-like gene at $15 \mathrm{ng} / \mathrm{g} \mathrm{BPA}$; no significant changes were observed for the lysosomal protease cathepsin L (data not shown). 


\subsection{Effects of BPA on antioxidant enzyme activities and glutathione content.}

BPA exposure also modulated the activities of enzymes involved in maintenance of redox balance (Fig. 3). As shown in Fig. 3A, catalase specific activity showed a significant decrease in response to the two lower concentrations of BPA $(-19 \%$ and $-13 \%$ with respect to controls, respectively; $\mathrm{P} \leq 0.05)$, followed by an increase $(+24 \%, \mathrm{P} \leq 0.05)$ at the highest concentration. BPA exposure increased GST and GSR activity at lower concentrations (Fig. 3B and 3C), up $+63 \%$ and $+29 \%$ of control values at 15 and $3 \mathrm{ng} / \mathrm{g}$, respectively $(\mathrm{P} \leq 0.05)$ and increased the total glutathione content at all the concentrations tested (about $+40 \%$ with respect to controls; $\mathrm{P} \leq 0.05$ ) (Fig. 3D).

\subsection{Effects of BPA on lysosomal parameters}

Fig. 4 shows the effects of mussel exposure to BPA on lysosomal membrane stability (LMS) and neutral lipid and lipofuscin accumulation, evaluated in digestive gland cryostatic tissue sections. BPA induced a concentration-dependent decrease in LMS (Fig. 4A). At the same time, increased accumulation of NL was observed, up $+240 \%$ with respect to controls $(\mathrm{P} \leq 0.05)$ in mussels injected with the highest concentration of BPA (Fig. 4B). BPA did not affect the lysosomal content of lipofuscin, the end-product of lipid peroxidation (Fig. 4C).

No significant differences in the response to BPA were observed in males and females and in animals sampled at different times of the year (October or June). 


\section{Discussion}

The results demonstrate that BPA exposure significantly affected gene expression and functional parameters in Mytilus hepatopancreas. When compared with the results obtained in mussels exposed to exogenous $\mathrm{E}_{2}$ in the same experimental conditions (this work; Canesi et al., 2007) these data indicate that in invertebrates the xenoestrogen can induce changes in gene expression at concentrations comparable with those of the natural estrogen.

Partial sequences of the Mytilus edulis MeER1 and MeER2 have been recently identified that are expressed in gonads (Puinean et al., 2006). MeER1 clusters with vertebrate ERs, and the MeER1 protein sequence has the highest identity (60\%) with mouse and zebrafish Estrogen Related Receptor ERR $\gamma$ compared with the invertebrate Aplysia californica ER (37\%). MeER2 clusters with the invertebrate Aplysia ER and has the highest protein sequence identity with Aplysia and Octopus ERs (70\% and 66\%, respectively) and, among vertebrates, with the chicken ER $\alpha$ (51\%). Our data indicate that both MeERs are constitutively expressed in the hepatopancreas of control mussels, with MeER1 showing a higher basal expression than MeER2, and that BPA exposure induced distinct and significant changes in the level of the mRNA transcripts for both genes. In particular, a $50 \%$ decrease for MeER1 at $15 \mathrm{ng} / \mathrm{g}$ BPA and a two-fold increase for MeER2 at all the concentrations tested were observed. Smaller but significant increases in the transcription of both MeERs were observed with $\mathrm{E}_{2}$ at concentrations that were previously shown to affect the expression of other genes in the same experimental conditions (Canesi et al., 2007). In fish, BPA has been shown to increase expression of ER $\alpha$ in different tissues (Seo et al., 2006; Hayashi et al., 2007). Our data demonstrate that estrogenic compounds can modulate the expression of ER-like sequences also in invertebrates.

BPA exposure downregulated the transcription of the antioxidant enzyme catalase, that is responsible for decomposition of $\mathrm{H}_{2} \mathrm{O}_{2}$, and of the metallothionein isoform MT20; a significant decrease in the level of MT10 transcripts was also observed at the highest concentration tested. MTs play a role in protection against oxidative stress in different organisms (Vergani et al. 2005); 
in Mytilus, the MT-20 isoform is preferentially induced by oxidant agents (such as hydrogen peroxide) and cadmium, whereas MT-10 is the constitutive isoform that preferentially responds to essential metals, such as zinc (Lemoine and Laulier, 2003; Dondero et al., 2005). The effects of BPA were distinct from those previously observed in the same experimental conditions with $E_{2}$, that induced significant increases in the expression of both catalase and MT20 (Canesi et al., 2007). Modulation of MT expression seems to represent a significant target for xenoestrogen action in different organisms ( Gerpe et al., 2000; Sogawa et al., 2001; Werner et al., 2003; Gagnè et al., 2004). BPA, like $\mathrm{E}_{2}$ (Canesi et al., 2007), decreased the expression of Mytilus p53-like gene and did not affect the expression of the lysosomal protease cathepsin L (not shown) .

Overall, the results demonstrate significant changes in gene transcription in mussels injected with $\mathrm{E}_{2}$ or BPA. This route of exposure, that allows for direct administration of estrogens into the animal open circulatory system leading to distribution from the blood (hemolymph) to the tissues, including the hepatopancreas, has been largely utilised for evaluating the effects of natural and environmental estrogens in bivalve molluscs (Gagnè et al., 2001; Canesi et al., 2005, 2006, 2007; Le Curieux-Belfond et al., 2005; Gauthier-Clerc et al., 2006; Puinean and Rotchell, 2006). In Mytilus sp., exogenous $\mathrm{E}_{2}$ added to the seawater (200-2000 $\left.\mathrm{ng} / \mathrm{l}\right)$ is taken up and progressively metabolised (within 7 days) to an esterified, inactive form that is stored in the tissues, this indicating that mussels can tightly regulate the concentration of free $\mathrm{E}_{2}$ (Janer et al., 2005). In mussels exposed for 10 days to $E_{2}(200 \mathrm{ng} / \mathrm{l})$ in the seawater to ensure significant estrogen accumulation in the tissues, no significant changes were observed in the expression of ER- and Vitellogenin-like sequences in the gonad (Puinean et al., 2006). The lack of effect was mainly ascribed to homeostatic mechanisms of conversion of the excess $E_{2}$ into inactive esters in these organisms (Janer et al., 2005; Janer and Porte, 2007). On the other hand, changes in Vtg expression were observed in the gonad of mussels $48 \mathrm{hr}$ post-injection with $25 \mu \mathrm{g} \mathrm{E}_{2}$ (Puinean and Rotchell, 2006). Administration by this route probably allows to bypass the homeostatic mechanism of progressive metabolism to inactive compounds that occurs in the presence of exogenous $\mathrm{E}_{2}$ 
(Puinean et al., 2006; Puinean and Rotchell, 2006). Irrespectively of the route of administration, the concentrations of $\mathrm{E}_{2}$ and BPA utilised in the present work were much lower than those utilised by these Authors, and comparable to those found in environmental samples from marine coastal areas (1,2-53 ng/l for $\mathrm{E}_{2}$ and 1,5-1,88 ng/l for BPA, respectively; Pojana et al., 2004). Therefore, the effects observed after $24 \mathrm{hr}$ injection may be due to direct effects of the estrogens administered into the blood rather than to their large accumulation in the tissues.

BPA also significantly affected the activity of enzymes involved in maintenance of tissue redox balance. A decrease in catalase activity was observed at the two lower concentration tested, followed by an increase at the highest concentration; such a trend in enzyme activity partially reflected that observed for transcription of catalase mRNA and was opposite to that observed with $\mathrm{E}_{2}$ (Canesi et al., 2007). BPA stimulated GSR activity at the two lower concentrations, and such an increase may compensate for the decrease in catalase activity, allowing the continuous recycling of GSSG to GSH; moreover, BPA exposure resulted in an increase in total glutathione content. BPA also stimulated the activity of the phase II enzyme GST, this suggesting that some metabolism of BPA may occur by this route in the hepatopancreas. BPA bioaccumulation and clearance have been demonstrated in bivalves, with shorter half-lives at higher temperatures (Heinonen et al., 2002).

Overall, the results indicate that BPA affects components involved in the maintenance of the redox status by downregulating the expression of antioxidant genes, at the same time upregulating the activities of enzymes involved in glutathione metabolism. As a result of this, BPA exposure did not induce oxidative stress conditions in the tissue, as indicated by the absence of changes in the lysosomal content of lipofuscin, the end-product of lipid peroxidation, or in the tissue level of malondialdehyde (not shown). On the other hand, in the same experimental conditions, $\mathrm{E}_{2}$ mainly showed anti-oxidant effects, as indicated by upregulation of catalase and MT20 genes, increase in catalase specific activity and slight decrease in lipofuscin content (Canesi et al., 2007). The results obtained with BPA are in line with those obtained in mammalian systems, where the xenoestrogen can act both as a pro-oxidant and an antioxidant because BPA has antioxidant activities structurally 
(Kadoma and Fujisawa et al., 2000), while it shows pro-oxidant activity through the estrogen receptor or its metabolites (Knaak and Sullivan, 1966; Atkinson and Roy, 1995; Obata and Kubota, 2000; Kabuto et al., 2003).

BPA also induced significant changes in digestive gland lysosomal parameters that are related to the health status of bivalves (Moore et al., 2006). The effects were similar to those previously observed with $\mathrm{E}_{2}$ (Canesi et al., 2007), showing a dose-dependent decrease in LMS and increase accumulation of neutral lipids (NL). Increased NL accumulation in bivalve tissues indicates either increased synthesis or decreased utilisation of neutral lipids, as well as impairment of lysosomal lipases, leading to enhanced autophagy of the accumulated lipids in digestive cells often associated to lysosomal membrane destabilization (Moore et al., 2006). Overall, the results further support the hypothesis that the lysosomal system represents a significant target for estrogenic compounds in molluscan cells (Moore et al., 1978; Canesi et al., 2004a,b, 2006, 2007) like in mammalian cells (Szego et al., 1975). In bivalves, the hepatopancreas plays a central role in metabolism through intracellular digestion of food particles and in distribution of nutrients to reproductive tissues during gamete maturation (Dimitriadis et al., 2004). Therefore, the overall effects induced by BPA in this tissue may result in indirect effects on reproduction. This data addresses the importance of investigating alternative endpoints of estrogenic effects also in invertebrate species.

With regards to the possible mechanisms of action of BPA, both genomic and non genomic modes of action involving ER-like receptors, as well as receptor-independent mechanisms may participate in mediating the effects (Quesada et al., 2002; Walsh et al., 2005; Ropero et al., 2006; Watson et al., 2007). In mussel immunocytes, BPA was shown to interfere with signaling components whose activation plays a key role in mediating the effect of $\mathrm{E}_{2}$. In vitro, the effects of BPA were prevented or significantly reduced by the antiestrogen Tamoxifen, suggesting the involvement of ERs (Canesi et al., 2004b). Although BPA, like $\mathrm{E}_{2}$, activated ERK MAPKs, both in vitro and in vivo, the xenoestrogen induced dephosphorylation of p38 MAPK and of transcription factors (such as STAT5 and CREB) (Canesi et al., 2004b, 2005; Porte et al., 2006) that are activated 
by $\mathrm{E}_{2}$ (Canesi et al., 2004a, 2006). Moreover, the in vivo effects were observed at concentrations of BPA comparable to those of $E_{2}$ and to environmental exposure levels (Canesi et al., 2005). This data suggested that BPA could lead to negative modulation of the expression of certain genes secondary to downregulation of components of cytosolic kinase-mediated cascades. In mammalian systems, $\mathrm{E}_{2}$ and BPA exhibit both common and divergent gene regulation involving both ERdependent and ER-independent mechanisms (Singleton et al., 2004; Welshons et al., 2006). The results here obtained seem to support the hypothesis that also in molluscan cells the distinct effects of BPA and $\mathrm{E}_{2}$ may be ascribed to distinct modes of action of the two compounds.

Individual xenoestrogens can differ in their potency and temporal phasing of effects compared to $\mathrm{E}_{2}$, thus possibly disrupting some endocrine functions when acting in combination with physiological estrogens (Watson et al., 2007). In mussels, BPA exposure did not result in significant changes in the circulating levels of free $\mathrm{E}_{2}$ at $24 \mathrm{hr}$ post-injection (data not shown). However, it must be considered that in vivo estrogenic chemicals are generally more stable than $\mathrm{E}_{2}$ and circulating xenoestrogens may not be sequestered by plasma steroid-binding proteins; therefore, unmodulated action of these compounds on target tissues and cells may occur (Ropero et al., 2006; Welshons et al., 2006). Interestingly, several of the parameters affected by BPA in mussel hepatopancreas apparently showed a non monotonic dose-response curve, with stronger or more evident effects at lower concentrations. Such an effect is commonly observed with hormones, or drugs and chemicals that act via hormonal, receptor-mediated mechanisms. Although further experiments utilising a wider range of BPA concentrations, as well as comparisons with exposure to BPA dissolved in the sea water at low environmental concentrations (ng/l), are needed to confirm these observations, the results further support the hypothesis that lower, environmentally relevant doses of BPA should be used to assess the hazard posed by estrogenic chemicals to both wildlife and humans (vom Saals and Hughes, 2005; Welshons et al., 2006). 


\section{ACKNOWLEDGEMENTS}

We thank Prof. Marco Giovine and Dr Marina Pozzolini, Marine Biotechnology Laboratory, Advanced Biotechnology Center (ABC), Genoa, for their support in quantitative RT-PCR analyses. 


\section{References}

Anderson, O.K., Viarengo, A., Pampanin, D. 2006. The Stavanger Workshop, Biological Effects of Environmental Pollution (BEEP) in marine coastal ecosystem - The Stavanger mesocosm exposure studies. Aquat. Toxicol. IRIS and Akvamiljo Eds.; 2006; 78, Supplement 1, pp. S1S128.

Atkinson, A., Roy, D., 1995. In vivo conversion of the environmental estrogenic chemical bisphenol A to DNA binding metabolite(s). Biochem. Biophys. Res. Commun. 210, 424-433.

Canesi, L., Viarengo, A., 1997. Age-related differences in glutathione metabolism in mussel tissues (Mytilus edulis L.). Comp. Biochem. Physiol. 116B, 217-221.

Canesi, L., Ciacci, C., Betti, M., Lorusso, L.C., Marchi, B., Burattini, S., Falcieri, E., Gallo, G., 2004a. Rapid Effect of 17beta-estradiol on cell signaling and function of Mytilus hemocytes. Gen. Comp. Endocrinol. 136, 58-71.

Canesi, L., Lorusso, L.C., Ciacci, C., Betti, M., Gallo, G., 2004b. Environmental estrogens can affect the function of mussel hemocytes through rapid modulation of kinase pathways. Gen. Comp. Endocrinol. 138, 58-69.

Canesi, L., Betti, M., Lorusso, L.C., Ciacci, C., Gallo, G., 2005. 'In vivo' effects of Bisphenol A in Mytilus hemocytes: modulation of kinase-mediated signalling pathways. Aquat. Toxicol. 71, 7384.

Canesi, L., Ciacci, C., Lorusso, L.C., Betti, M., Guarnieri, T., Tavolari, S., Gallo, G., 2006. Immunomodulation by $17 \beta$-Estradiol in bivalve hemocytes. Am. J. Physiol. Regul. Integr. Comp. Physiol. 291, R664-73.

Canesi, L., Borghi, C., Fabbri, R., Ciacci, C., Lorusso, L.C., Gallo, G:, Vergani, L., 2007. Effects of 17ß-Estradiol in mussel digestive gland. Gen. Comp. Endocrinol. doi:10.1016/ j.ygen.2007.02.005, in press. 
Dimitriadis, V.K., Domouhtsidou, G.P., Cajaraville, M.P., 2004. Cytochemical and histochemical aspects of the digestive gland of the mussel Mytilus galloprovincialis (L.) in relation to function. J. Mol. Histol. 35, 501-509.

Dondero, F., Piacentini, L., Banni, M., Rebelo, M., Burlando, B., Viarengo, A., 2005. Quantitative PCR analysis of two molluscan metallothionein genes unveils differential expression and regulation. Gene 345, 259-270.

Dondero, F., Piacentini, L., Marsano, F., Rebelo, M., Vergani, L., Venier, P., Viarengo, A., 2006. Gene transcription profiling in pollutant exposed mussels (Mytilus spp.) using a new lowdensity oligonucleotide microarray. Gene 376, 24-36.

Gauthier-Clerc, S., Pellerin, J., Fournier, M., Amiard, J.-C., 2006. Immunological and biochemical responses in Mya arenaria (Mollusca Bivalvia) exposed in vivo to estradiol 17- $\beta$. Comp. Biochem. Physiol. 144C, 228-34

Gagnè F., Blaise, C., Salazar, M., Salazar, S., Hansen, P.D., 2001. Evaluation of estrogenic effects of municipal effluents to the freshwater mussel Elliptio complanata. Comp. Biochem. Physiol. $128 \mathrm{C}, 213-255$.

Gagnè, F., Blaise, C., Helou, J., 2004. Endocrine disruption and health effects of caged mussels, Elliptio complanata, placed downstream from a primary-treated municipal effluent plume for 1 year. Comp. Biochem. Physiol. 138C, 33-44.

Gerpe, M., Kling, P., Berg, A.H., Olsson, P.E., 2000. Arctic char (Salvelinus alpinus) metallothionein: cDNA sequence, expression, and tissue-specific inhibition of cadmium mediated metallothionein induction by 17b-estradiol, 4-OH-PCB 30, and PCB 104. Environ. Toxicol. Chem. 19, 638-645.

Gould, J.C., Leonard, L.S., Maness, S.C., Wagner, B.L., Conner, K., Zacharewski, T., Safe, S., McDonnel, D.P., Gaido, K.W., 1998. Bisphenol A interacts with the estrogen receptor alpha in a distinct manner from estradiol. Mol. Cell. Endocrinol. 142, 203-214.

Hayashi, H., Nishimoto, A., Oshima, N., Iwamuro, S., 2007. Expression of the estrogen receptor 
alpha gene in the anal fin of japanese medaka, Oryzias latipes, by environmental concentrations of Bisphenol A. J. Toxicol. Sci., 32, 91-96.

Heinonen, J. Honkanen, J. Kukkonen, J. V. K., Holopainen, I. J., 2002. Bisphenol A accumulation in the freshwater clam Pisidium amnicum at low temperatures Arch. Environ. Contam. Toxicol. $43,50-55$.

Janer, G., Lavado, R., Thibaut, R., Porte, C., 2005. Effects of $17 \beta$-estradiol exposure in the mussel Mytilus galloprovincialis: a possible regulating role for steroid acyltransferases. Aquat. Toxicol. $75,32-42$.

Janer G, Porte C., 2007 Sex steroids and potential mechanisms of non-genomic endocrine disruption in invertebrates. Ecotoxicology 16, 1 45-60.

Jobling, S., Casey, D., Rogers-Gray, T., Oehlmann, J., Schulte-Ohelmann, U., Pawlowski, S., Baunbeck, T., Turner, A.P., Tyler, C.R., 2003. Comparative responses of molluscs and fish to environmental estrogens and an estrogenic effluent. Aquat. Toxicol. 66, 207-222.

Kabuto, H., Hasuike, S., Minagawa, N., Shishibori, T., 2003. Effects of bisphenol A on the metabolisms of active oxygen species in mouse tissues. Environ. Res. 93, 31-35

Kadoma, Y., Fujisawa, S., 2000. Kinetic evaluation of reactivity of bisphenol A derivatives as radical scavengers for methacrylate polymerization. Biomaterials 21, 2125-2130.

Kajiwara, M., Kuraku, S., Kurokawa, T., Kato, K., Toda, S., Hirose, H., Takahashi, S., Shibata, Y., Iguchi, T., Matsumoto, T., Miyata, T., Miura, T., Takahashi, Y., 2006. Tissue preferential expression of estrogen receptor gene in the marine snail, Thais clavigera. Gen. Comp. Endocrinol. 148, 315-26.

Keay, J., Bridgham, J.T., Thornton, J.W., 2006. The Octopus vulgaris estrogen receptor is a constitutive transcriptional activator: evolutionary and functional implications. Endocrinology $147,3861-3869$.

Knaak, J., Sullivan, L.J., 1966. Metabolism of bisphenol A in the rat. Toxicol. Appl. Pharmacol. 8, $175-184$. 
Le Curieux-Belfond, O., Fievet, B., Sèralini, G.E., Mathieu, M., 2005. Short-term bioaccumulation, circulation and metabolism of estradiol-17ß in the oyster Crassostrea gigas. J. Exp. Mar. Biol. Ecol., 325, 125-133.

Lemoine, S., Laulier, M., 2003. Potential use of the levels of the mRNA of a specific metallothionein isoform (MT-20) in mussel as a biomarker of cadmium contamination. Mar. Pollut. Bull. 46, 1450-1455.

Levin, E.R., 2005. Integration of the extranuclear and nuclear actions of estrogen. Mol. Endocrinol. $19,1951-1959$.

Maffini, M.V., Rubin, B.S., Sonnenschein, C., Soto, A.M., 2006. Endocrine disruptors and reproductive health: the case of bisphenol-A. Mol. Cell. Endocrinol. 255, 179-186.

McLachlan, J.A., 2001. Environmental signalling: what embryos and evolution teach us about endocrine disrupting chemicals. Endocrine Rev. 22, 319-341.

Moore, M.N., 1976. Cytochemical demonstration of latency of lysosomal hydrolases in digestive gland cells of the common mussel Mytilus edulis, and changes induced by thermal stress. Cell Tissue Res. 175, 279-287.

Moore, M.N., 1988. Cytochemical responses of the lysosomal system and NADPHferrihemoprotein reductase in molluscan digestive cells to environmental and experimental exposure to xenobiotics. Mar. Ecol. Prog. Ser. 46, 81-89.

Moore, M.N., Allen, J.I., McVeigh, A., 2006. Environmental prognostics: an integrated model supporting lysosomal stress responses as predictive biomarkers of animal health status. Mar. Environ. Res. 61, 278-304.

Moore, M.N., Lowe, D.M., Fieth, P.E.M., 1978. Responses of lysosomes in the digestive cells of the common mussel Mytilus edulis, to sex steroids and cortisol. Cell Tissue Res. 188, 1-9.

Obata, T., Kubota, S. 2000. Formation of hydroxy radicals by environmental estrogen-like chemicals in rat striatum. Neurosci Lett. 296, 41-44.

Ohelmann, J., Schulte-Ohelmann, U., Bachmann, J., Oetken, M., Lutz, I., Kloas, W., Ternes, T.A., 
2006. Bisphenol A induces superfeminisation in the ramshorn snail Marisa cornuarietis (Gastropoda: prosobranchia) at environmental relevant concentrations. Environ. Health Perspect. 114, 127-133.

Pfaffl, M.W., 2001. A new mathematical model for relative quantification in real-time RT-PCR. Nucleic Acids Res. 29:e45.

Pojana, G., Bonfà, A., Busetti, F., Collarin, A., Marcomini, A. 2004. Estrogenic potential of the Venice, Italy, Lagoon waters. Environ. Toxicol. Chem. 23, 1874-1880

Porte, C., Janer, G., Lorusso, L.C., Ortiz-Zarragoitia, M., Cajaraville, M.P., Fossi, M.C., Canesi, L., 2006. Endocrine disruptors in marine organisms: approaches and perspectives. Comp. Biochem. Physiol. 143C, 303-315.

Puinean AM, Rotchell JM. 2006. Vitellogenin gene expression as a biomarker of endocrine disruption in the invertebrate, Mytilus edulis. Mar. Environ. Res. 62 Suppl. S211-214.

Puinean, A.M., Labadie, P., Hill, E.M., Osada, M., Kishida, M., Nakao, R., Novillo, A., Callard, I.P., Rotchell, J.M., 2006. Laboratory exposure to $17 \beta$-estradiol fails to induce vitellogenin and estrogen receptor gene expression in the marine invertebrate Mytilus edulis. Aquat. Toxicol. 79, $376-383$.

Quesada, I., Fuentes, E., Viso-Leon, M.C., Soria, B., Ripoll, C., Nadal, A., 2002. Low doses of the endocrine disruptor Bisphenol $\mathrm{A}$ and the native hormone 17beta-estradiol rapidly activate transcription factor CREB. FASEB J. 16, 1671-1673.

Ropero, A.B., Alonso-Magdalena P., Ripoll, C., Fuentes, E., Nadal, A., 2006. Rapid endocrine disruption: environmental estrogn actions triggered outside the nucleus. J. Steroid Biochem. Mol. Biol. 102, 163-169.

Rotchell, J.M., Ostrander, G.K., 2003. Molecular effects of endocrine disrupters in aquatic organisms. J. Toxicol. Environ. Health. 6B, 453-495.

Seo, J.S., Lee, Y.M., Jung, S.O., Kim, I.C., Yoon, Y.D., Lee, J.S., 2006. Nonylphenol modulates expression of androgen receptor and estrogen receptor genes differently in gender types of the 
hermaphroditic fish Rivulus marmoratus. Biochem. Biophys. Res. Commun. 346, 213-223.

Singleton, D.W., Feng, Y., Chen, Y., Busch, S.J., Lee, A.V., Puga, A., Khan, S.A., 2004.

Bisphenol-A and estradiol exert novel gene regulation in human MCF-7 derived breast cancer cells. Mol. Cell. Endocrinol. 221, 47-55.

Sogawa, N., Onodera, K., Sogawa, C.A., Mukubo, Y., Fukuoka, H., Oda, N., Furuta, H., 2001. Bisphenol A enhances cadmium toxicity through estrogen receptor. Methods Find Exp Clin Pharmacol. 23, 395-399.

Soto, A.M., Maffini, M.V., Schaeberle, C.M., Sonnenschein, C., 2006. Strenghts and weaknesses of in vitro assay for estrogenic and androgenic activity. Best. Pract. Res. Clin. Endocrinol. Metab. 20, 15-33.

Stefano, G.B., Cadet, P., Mantione, K., Cho, J.J., Jones, D., Zhu, W., 2003. Estrogen signalling at the cell surface coupled to nitric oxide release in Mytilus edulis nervous system. Endocrinology $144,1234-1240$.

Szego, C.M., 1975. Lysosomal function in nucleocytoplasmic communication. In: Dingle, J.T., Dean, R. (Eds.), Lysosomes in Biology and Pathology. Elsevier, Amsterdam, pp. 385-477.

Tabb, M.M., Blumberg, B., 2006. News modes of action for endocrine-disrupting chemicals. Mol. Endocrinol. 20, 475-482.

Thornton, J.W., Need, E., Crews, D., 2003. Resurrecting the ancestral steroid receptor: ancient origin of estrogen signaling. Science $301,1714-1717$.

Vandesompele, J., De Preter, K., Pattyn, F., Poppe, B., Van Roy, N., De Paepe, A., Speleman, F., 2002. Accurate normalization of real-time quantitative RT-PCR data by geometric averaging of multiple internal control genes. Genome Biol. 3, RESEARCH0034.

Vasudevan, N., Pfaff, D.W., 2007. Membrane-initiated actions of estrogens in neuroendocrinology: emerging principles. Endocrine. Rev. 28, 1-19.

Vergani L, Grattarola M, Borghi C, Dondero F, Viarengo A. 2005, Fish and molluscan metallothioneins. FEBS J. 272, 6014-23. 
Viarengo, A., Canesi, L., Pertica, M., Livingstone, D.R., 1991. Seasonal variation of antioxidant defence systems and lipid peroxidation in the digestive gland of mussels. Comp. Biochem Physiol. 100C, 187-190.

vom Saal FS, Hughes C., 2005. An extensive new literature concerning low-dose effects of bisphenol A shows the need for a new risk assessment. Environ. Health Perspect. 113, 926-933.

Walsh, D.E., Dockery, P., Doolan, C.M., 2005. Estrogen receptor independent rapid non-genomic effects of environmental estrogens on $\left[\mathrm{Ca}^{2+}\right] \mathrm{i}$ in human breast cancer cells. Mol. Cell. Endocrinol. 230, 23-30.

Waring, R.H., Harris, R.M., 2005. Endocrine disrupters: a human risk?. Mol. Cell. Endocrinol. 244, 2-9.

Watson, C.S., Bulayeva, N.N., Wozniak, A.L., Alyea, R.A., 2007. Xenoestrogens are potent activators of nongenomic estrogenic responses. Steroids 72, 124-134.

Welshons, W.V., Nagel, S.C., vom Saal, F.S., 2006. Large Effects from Small Exposures. III. Endocrine Mechanisms Mediating Effects of Bisphenol A at Levels of Human Exposure. Endocrinology 147, (6) (Supplement):S56-S69.

Werner, J., Wautier, K., Evans, R.E., Baron, C.L., Kidd, C.L., Palace, V., 2003. Waterborne ethynylestradiol induces vitellogenin and alters metallothionein expression in lake trout (Salvelinus namaycush). Aquat. Toxicol. 62, 321-328. 


\section{Figure Legends}

Fig. 1 - Expression of MeER transcripts in Mytilus galloprovincialis hepatopancreas and effects of exposure to BPA and $\mathrm{E}_{2}$. A) RT-PCR of MeER1 and MeER2 in the hepatopancreas of control mussels; B) and C): Quantitative RT-PCR of MeER1 and MeER2 in BPA- and $E_{2}$-exposed mussels. Mussels were injected with different amounts of BPA (nominal concentrations 3, 15 and $60 \mathrm{ng} / \mathrm{g} \mathrm{dw}$, respectively) or $\mathrm{E}_{2}$ (1.35 or $6.75 \mathrm{ng} / \mathrm{g} \mathrm{dw}$, respectively) or vehicle (ethanol), and tissues sampled 24 hrs post-injection. Relative expression was calculated with respect to controls as described in Methods. Data are the mean \pm SD from of three experiments in triplicate. $*=P \leq 0.05$, Mann-Whitney U test.

Fig. 2 - Effects of BPA exposure on the transcription of Mytilus genes in the hepatopancreas: catalase, MT20, MT10, p53. Mussels were injected with different amounts of BPA (nominal concentrations 3,15 and $60 \mathrm{ng} / \mathrm{g} \mathrm{dw}$, respectively) or vehicle (ethanol) as described in methods and tissues sampled 24 hrs post-injection. Gene expression was determined quantitative RT-PCR and relative expression was calculated with respect to controls as described in Methods. Data are the mean $\pm \mathrm{SD}$ from of three experiments in triplicate. ${ }^{*}=\mathrm{P} \leq 0.05$, Mann-Whitney $\mathrm{U}$ test.

Fig. 3 - Effect of BPA exposure on enzyme activities and glutathione content in Mytilus galloprovincialis. A) Catalase; B) GST-GSH transferase; C) GSR-GSSG reductase; D) total glutathione (GSH+1/2 GGSG). Mussels were injected with different amounts of BPA (nominal concentrations 3, 15 and $60 \mathrm{ng} / \mathrm{g} \mathrm{dw}$, respectively) or vehicle (ethanol) as described in methods and tissues sampled $24 \mathrm{hrs}$ post-injection. Catalase activity was measured in both the 12,000 x $\mathrm{g}$ supernatant and pellet as described in methods, and expressed as $\% \mu$ moles $\mathrm{H}_{2} \mathrm{O}_{2}$ consumed $/ \mathrm{min} / \mathrm{mg}$ prot with respect to controls. Data are the mean $\pm \mathrm{SD}$ of three experiments in triplicate; $*=\mathrm{P} \leq 0.05$, Mann-Whitney U test. 
Fig. 4 - Effect of BPA exposure on lysosomal parameters in Mytilus galloprovincialis hepatopancreas. A) Lysosomal membrane stability (LMS); B) neutral lipid accumulation; C) lipofuscin content. Mussels were injected with different amounts of BPA (nominal concentrations 3, 15 and $60 \mathrm{ng} / \mathrm{g} \mathrm{dw}$, respectively) or vehicle (ethanol) as described in methods and tissues sampled 24 hrs post-injection. Data are the mean $\pm \mathrm{SD}(\mathrm{n}=10) ; *=\mathrm{P} \leq 0.05$, Mann-Whitney U test. 

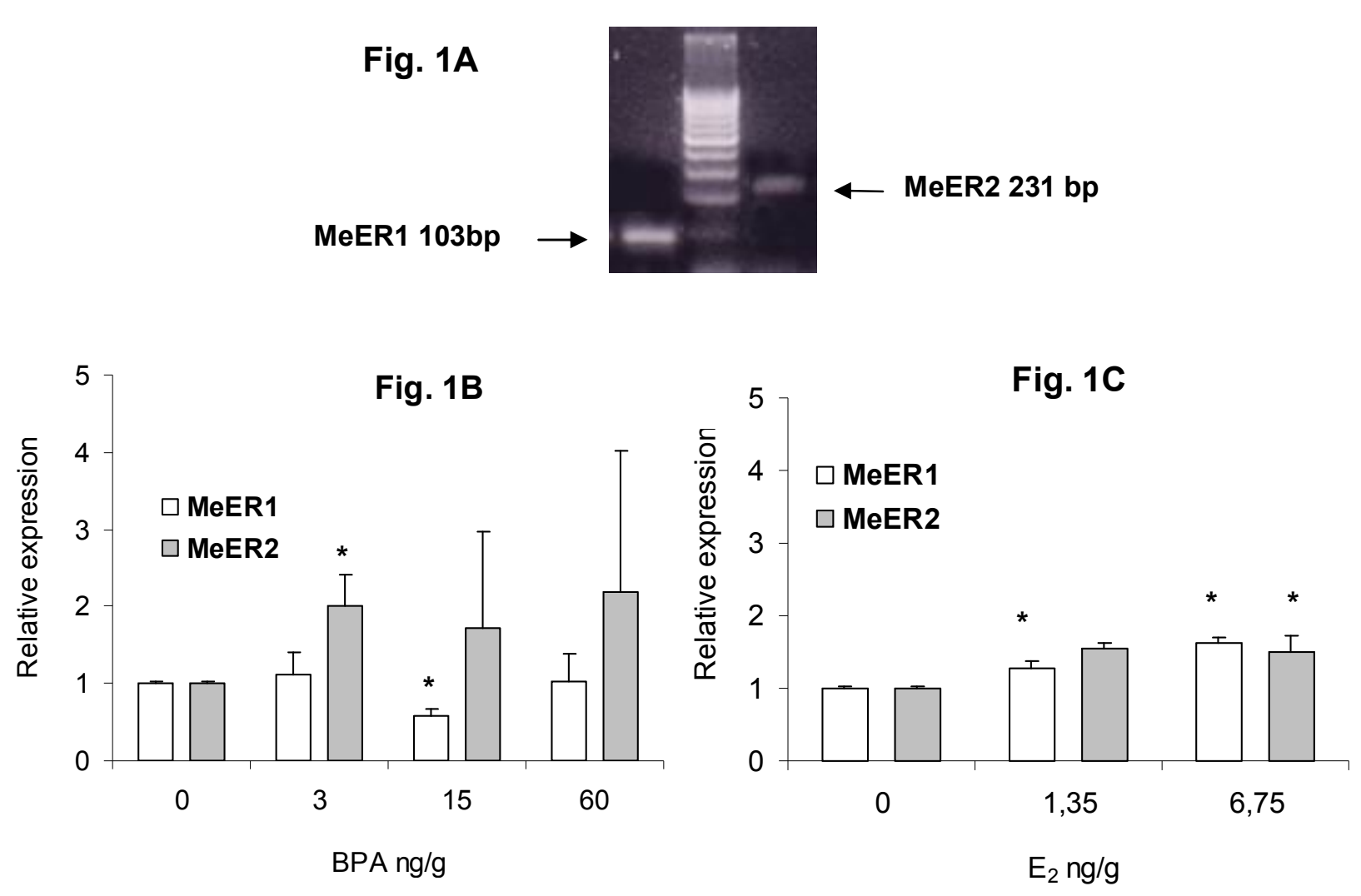

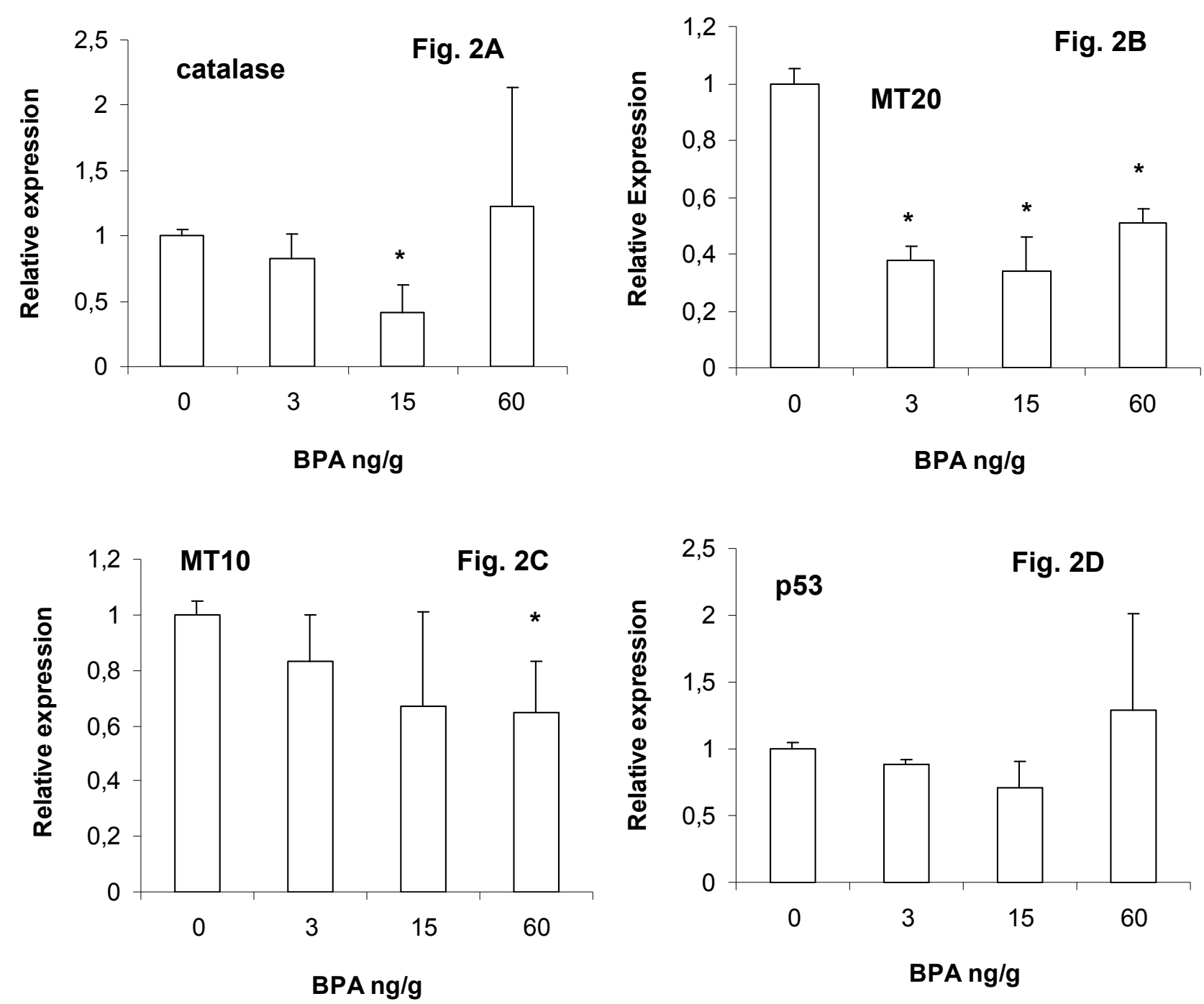

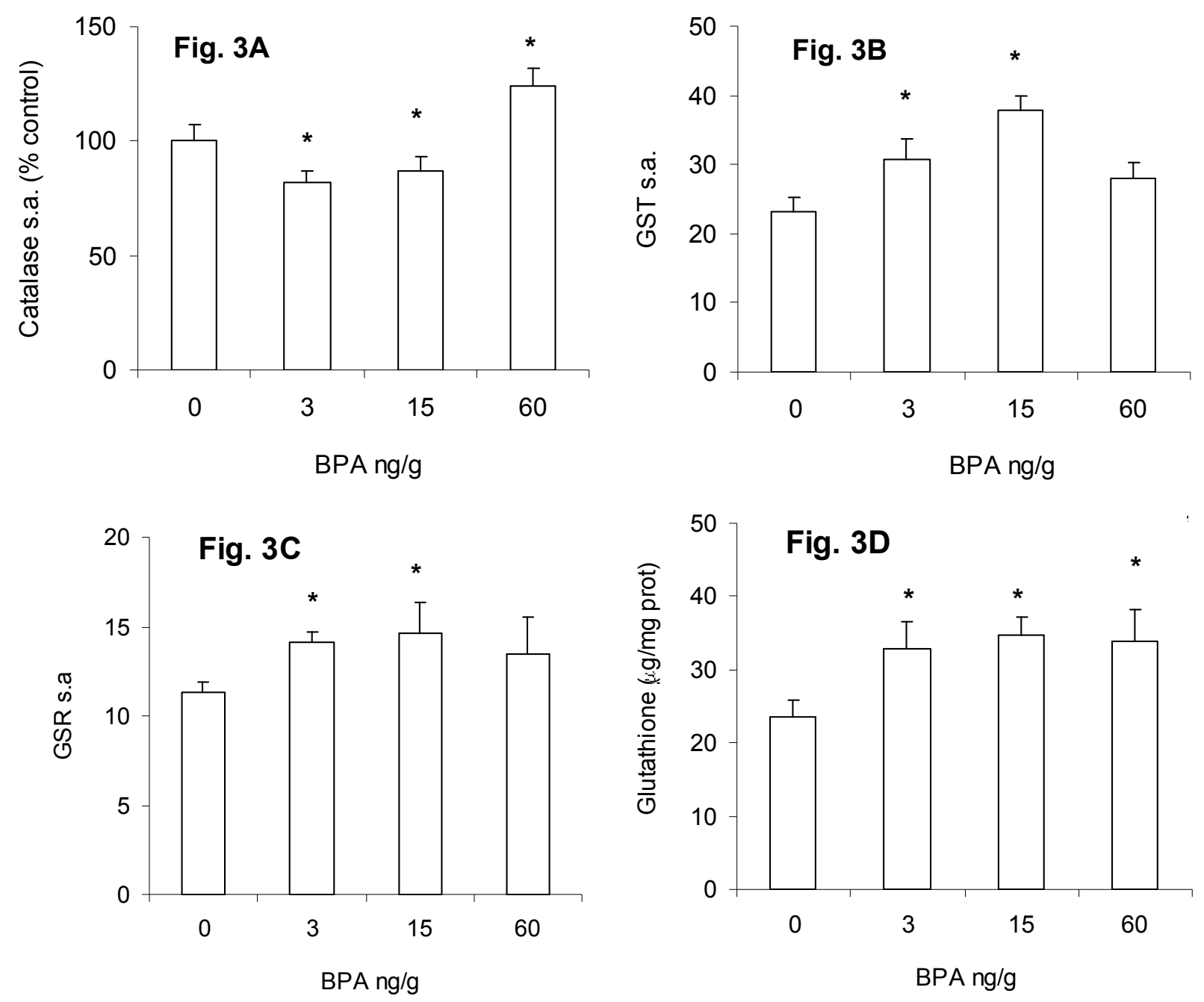

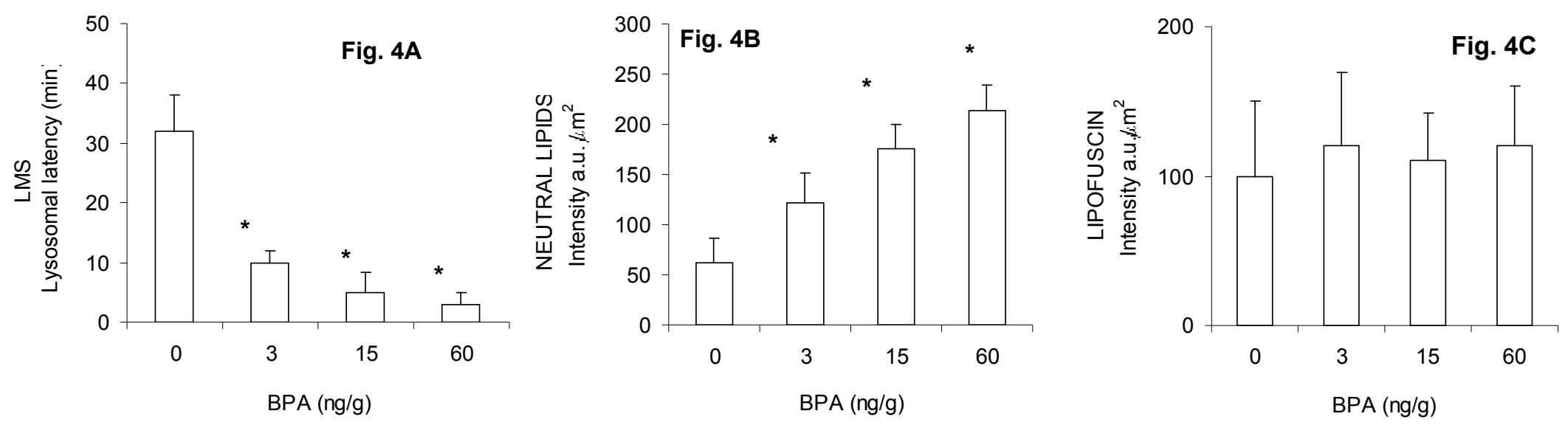

Page 31 of 32 
Tab.1 - Oligonucleotide primers used for RT-Q-PCR analysis.

\begin{tabular}{|c|c|c|c|c|}
\hline Gene & Forward & Reverse & $\begin{array}{l}\text { GenBank } \\
\text { accession }\end{array}$ & References \\
\hline MT10 & 5’-GGGCGCCGACTGTAAATGTTC-3’ & 5'-CACGTTGAAGGCCTGTACACC-3’ & $\underline{\mathrm{AY} 566248}$ & $\begin{array}{c}\text { Dondero et } \\
\text { al., } 2005\end{array}$ \\
\hline MT20 & 5'-TGTGAAAGTGGCTGCGGA-3' & 5’-GTACAGCCACATCCACACGC-3’ & $\underline{\mathrm{AY} 566247}$ & $\begin{array}{c}\text { Dondero et } \\
\text { al., } 2005\end{array}$ \\
\hline p53-like & 5'-CСAACTTGCTAAATTTGTTGAAGA-3' & 5’TTGGTCCTCCTACACATGAC-3' & $\underline{\text { DQ158079 }}$ & $\begin{array}{c}\text { Dondero et } \\
\text { al., } 2006\end{array}$ \\
\hline Catalase & 5'-CGACCAGAGACAACCCACC-3' & 5’-GCAGTAGTATGCCTGTCCATCC-3' & $\underline{\text { AY743716 }}$ & \\
\hline CathepsinL & 5'-CGCAGCTAATGTTGGCGCC-3' & 5’-CTACGGCGATTGGTCCCTG-3' & $\underline{\text { AY618311 }}$ & \\
\hline $18 \mathrm{~S}$ & 5'-TCGATGGTACGTGATATGCC-3' & 5’-CGTTTCTCATGCTCССТCTC-3’ & $\underline{\text { L33451 }}$ & $\begin{array}{c}\text { Dondero et } \\
\text { al., } 2005\end{array}$ \\
\hline MeER1 & 5'-TTACGAGAAGGTGTGCGTTTT-3’ & 5'-TCACCATAGGAAGGATATGT-3', & $\underline{\text { AB257132 }}$ & $\begin{array}{c}\text { Puinean et } \\
\text { al., } 2006\end{array}$ \\
\hline MeER2 & 5'-GGAACACAAAGAAAAGAAAGGAAG-3' & 5’-ACAAATGTGTTCTGGATGGTG-3' & $\underline{\text { AB257133 }}$ & $\begin{array}{c}\text { Puinean et } \\
\text { al., } 2006\end{array}$ \\
\hline
\end{tabular}

